\title{
Expression of Transcription Factor GATA-6 in Alveolar Epithelial Cells Is Linked to Neonatal Lung Disease
}

\author{
Riika Vähätalo ${ }^{a, c}$ Tiina M. Asikainen ${ }^{a, f}$ Riitta Karikoski ${ }^{b}$ Vuokko L. Kinnula ${ }^{d}$ \\ Carl W. White ${ }^{f}$ Sture Andersson $^{\text {a, c }}$ Markku Heikinheimo ${ }^{\text {a, c, e }}$ \\ Marjukka Myllärniemic, d

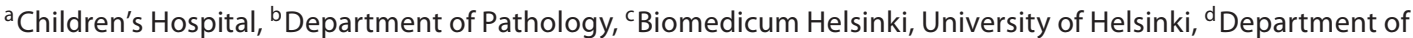 \\ Pulmonary Medicine, Helsinki University Central Hospital and University of Helsinki, Helsinki, Finland; e Department

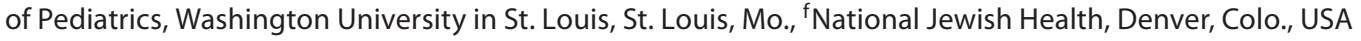

\section{Key Words}

Transcription factor GATA- 6 • Lung development •

Respiratory distress syndrome $\cdot$ Bronchopulmonary

dysplasia

\begin{abstract}
Background: Premature birth and respiratory distress syndrome (RDS) are risk factors for disturbed lung development and bronchopulmonary dysplasia (BPD). The molecular mechanisms related to prematurity and BPD remain largely unknown. Epithelial expression of the transcription factor GATA- 6 has been implicated in normal and abnormal murine lung development. Objectives: The possible involvement of GATA- 6 in the normal development and in RDS and BPD was investigated in the human and baboon lung. Methods: Immunohistochemistry was used to study the expression of GATA- 6 and thyroid transcription factor 1 in lung specimens from different age groups of human and baboon fetuses and newborns with lung disease. Furthermore, the regulatory role of TGF- $\beta_{1}$ in GATA- 6 expression was investigated in human pulmonary epithelial cell lines using RT-PCR. Results: GATA- 6 expression increased in the developing human airway epithelium along with advancing gestation, but diminished to negligible at birth. In RDS, GATA- 6 expression was
\end{abstract}

enhanced at 5-7 days after birth, and decreased thereafter. In BPD, the expression of GATA- 6 in alveolar epithelial cells was low. These results were confirmed and extended using an established baboon model of prematurity. The in vitro experiments revealed that TGF- $\beta_{1}$ induces GATA- 6 and thyroid transcription factor 1 expression in lung epithelial cells. Conclusions: Our results suggest that the expression of GATA- 6 at the early stages of the preterm lung may be related to impaired postnatal alveolar development.

Copyright $\odot 2010$ S. Karger AG, Basel

\section{Introduction}

Premature birth, oxygen toxicity and mechanically induced ventilation are probably the most important factors that disturb the stringently controlled normal lung development. Prematurity often leads to newborn respiratory distress syndrome (RDS), characterized by pulmonary inflammation and edema [1].

Despite the improved care of acute RDS, the incidence of bronchopulmonary dysplasia (BPD) has remained high in small preterm infants [2]. The pathogenesis of BPD is believed to consist of several components each contributing to impaired alveolarization $[3,4]$. The main

\section{KARGER}

(ㄷ) 2010 S. Karger AG, Basel

Fax +41 613061234

E-Mail karger@karger.ch

www.karger.com www.karger.com/neo
Markku Heikinheimo, MD, PhD

Children's Hospital

University of Helsinki

PO Box 20, FI-00014 Helsinki (Finland)

Tel. +3589 4717 4770, Fax +358 94717 5299, E-Mail markku.heikinheimo@ @elsinki.fi 
components are believed to be pre- and postnatal inflammation, as well as oxygen toxicity, which can further damage the lung [2]. The development of BPD has been also been linked to alterations in critical signaling pathways, such as in the TGF- $\beta$ superfamily [5].

Several factors are involved in the normal pulmonary development and pathophysiology of neonatal lung disease. Transcription factors are essential regulators of gene expression, and their abnormalities have been associated with disease in several organs. GATA transcription factors are zinc finger proteins that recognize a consensus DNA sequence (A/T) GATA (A/G), known as GATA-motif, which is an essential cis-acting element in the promoters and enhancers of a variety of genes [6]. GATA-4, GATA-5, and GATA- 6 are expressed in the foregut or cardiac regions of the developing embryo, suggesting a potential role in organogenesis of the heart and lung [7-9]. These GATA proteins are also expressed in the developing mouse lung [8-11].

Out of the three GATA factors implicated in lung development, GATA- 6 has been most extensively studied in the developing airway epithelium [9]. Conditional loss of function mouse models revealed that GATA- 6 is required for lung maturation at the saccular stage [12]. A generalized delay in lung maturation and decreased surfactant protein $B$ levels were observed in this model, and postnatal survival was decreased in comparison with wild-type littermates [12]. The expression of GATA-6 is normally downregulated at term in murine lung, and this seems to be essential for proper lung maturation, whereas overexpressing GATA- 6 in the postnatal respiratory epithelial type II cells inhibits alveolarization and perturbs lung function [13]. Subsequent studies on murine lung have shown that GATA- 6 enhances transcription of surfactant $A$ and $C$ genes $[14,15]$. In addition, it interacts with thyroid transcription factor 1 (TTF-1), also involved in the regulation of surfactant gene expression $[14,16]$. TTF-1 on the other hand regulates thyreoglobulin, the macromolecular precursor of thyroid hormones, which in turn may be involved in orchestrating the complex steps involved in lung morphogenesis [17].

Collectively, the published data on experimental models suggest that GATA-6, together with its cofactors and downstream target genes, has a central role in normal mammalian lung development and function. We postulated that abnormalities in the expression of GATA- 6 might also be associated with abnormal lung development in primates, and assessed its expression during fetal and neonatal human lung development and disease. As the overexpression of TGF- $\beta$ in the neonatal mouse lung results in histological changes similar to BPD [18], and TGF- $\beta$ is known to contribute to postnatal fibrosis after alveolar injury $[5,19]$, the relationship of GATA- 6 and TGF- $\beta$ in pulmonary epithelial cells was studied in vitro.

\section{Materials and Methods}

\section{Human Lung Tissue}

The human lung biopsies were obtained from autopsy material (Children's Hospital, Helsinki University Central Hospital) of fetal or preterm/term infants, taken within 3 days post-mortem (table 1). The permission to use the material in scientific purposes was obtained from the National Authority for Medicolegal Affairs. The samples were divided into three different groups according to the patient's age and specific diagnosis: (1) fetus; (2) newborn at term; (3) preterm with RDS at 1-2 days after birth; (4) preterm with RDS at 3-7 days after birth; (5) preterm with RDS at 7 days or more after birth, and (6) preterm with BPD. BPD was defined using the published criteria [20]. Antenatal betamethasone treatment was not part of the clinical routine at the time of sample collection, and none of the patients received prophylactic glucocorticoid treatment during the early postnatal period.

\section{Premature Primate Model}

All animal studies were performed at the Southwest Foundation for Biomedical Research Primate Center (San Antonio, Tex., USA) and protocols and procedures were approved by the Institutional Animal Care and Use Committee. Fetal baboons (gestational controls, GCs) of varying gestational ages $(125, \mathrm{n}=6 ; 140$, $\mathrm{n}=5 ; 160, \mathrm{n}=4 ; 175, \mathrm{n}=4, \pm 2$ days) were delivered by hysterotomy and euthanized at birth before onset of breathing. The lung samples from term animals $(185+2$ days, $\mathrm{n}=6)$ were collected following term natural delivery. The preterm animals $(125+2$ days, $\mathrm{n}=4 ; 125+6$ days, $\mathrm{n}=4 ; 125+14$ days, $\mathrm{n}=6 ; 125+21$ days, $\mathrm{n}=5$ ), also delivered by hysterotomy, were resuscitated, placed on ventilatory support with pro re nata (PRN) $\mathrm{O}_{2}$, and cared for as previously described [21, 22]. 125 and 140 days of baboon gestation correspond to 27 and 32 human gestational weeks, respectively. The $125+14$ or 21 days $\mathrm{PRN} \mathrm{O}_{2}$ animals develop lung histopathological lesions similar to human BPD [21]. All samples were collected during years 1996-2004, and at necropsy they were immediately fixed with $4 \%$ paraformaldehyde.

\section{Immunohistochemistry}

Immunoperoxidase staining of human and baboon samples for GATA- 6 and human samples for TTF-1 followed the protocol previously described [23]. Rabbit polyclonal GATA-6 (Santa Cruz Biotechnology; dilution $1: 200)$ and mouse monoclonal antiTTF-1 (8G7G3/1; Abcam; dilution 1:100), primary antibodies were used for the staining. The primary antibodies were incubated overnight at $+4^{\circ} \mathrm{C}$. In control experiments, nonimmune serum (Sigma; I $8140-10 \mathrm{mg}$ ) replaced the primary antibody, or the sections were incubated with secondary antibody without primary antibody. For each sample, approximately 10 areas of stained sections were evaluated by 2 observers (R.V. and R.K.). For human samples, the proportion of positivity to each nuclear antigen was evaluated as follows: low intensity $(+)$ for $0-20 \%$ positive nuclei or $1-80 \%$ positive cells with weak immunoreactivity, intermediate 
Table 1. Human patient characteristics and GATA-6 and TTF-1 immunohistochemistry scored from 1 to 3

\begin{tabular}{|c|c|c|c|c|c|c|c|}
\hline Patient & $\begin{array}{l}\text { Gestational } \\
\text { age, weeks }\end{array}$ & $\begin{array}{l}\text { Birth } \\
\text { weight, g }\end{array}$ & $\begin{array}{l}\text { Age at } \\
\text { death }\end{array}$ & Sex & Cause of death & GATA-6 & TTF-1 \\
\hline \multicolumn{8}{|l|}{ Fetus } \\
\hline 1 & 14 & 30 & - & $\mathrm{F}$ & meningomyelocele & +++ & +++ \\
\hline 2 & $18-19$ & 162,43 & - & M & meningomyelocele & ++ & +++ \\
\hline 3 & $20+2$ & 346 & - & $\mathrm{F}$ & HLHS & +++ & +++ \\
\hline \multicolumn{8}{|l|}{ Term } \\
\hline 4 & $39+5$ & 3,985 & 7 days & $\mathrm{F}$ & HLHS & - & - \\
\hline 5 & $40+6$ & 3,220 & 25 days & $\mathrm{F}$ & heart defect & - & - \\
\hline 6 & 41 & 3,300 & 22 days & M & heart defect & + & - \\
\hline 7 & $41+1$ & 3,150 & 16 days & $\mathrm{M}$ & heart defect & - & - \\
\hline \multicolumn{8}{|c|}{ Early RDS (1-2 days) } \\
\hline 8 & $24+5$ & 740 & 2 days & $\mathrm{F}$ & RDS, preterm & + & ++ \\
\hline 9 & $25+6$ & 887 & 1 days & M & RDS, IVH & + & ++ \\
\hline 10 & 26 & 720 & 1.5 days & $\mathrm{F}$ & RDS & - & + \\
\hline 11 & $26+2$ & 920 & $3 \mathrm{~h}$ & $\mathrm{~F}$ & RDS, preterm & - & +++ \\
\hline \multicolumn{8}{|c|}{ Prolonged RDS (3-7 days) } \\
\hline 12 & $23+6$ & 700 & 3 days & M & RDS, IVH, preterm & ++ & +++ \\
\hline 13 & $24+6$ & 812 & 6 days & $\mathrm{F}$ & RDS, IVH, preterm & $+/++$ & + \\
\hline 14 & $25+1$ & 770 & 3 days & $\mathrm{M}$ & RDS, IVH, preterm & + & +++ \\
\hline 15 & $26+1$ & 750 & 4 days & $\mathrm{M}$ & RDS, IVH, preterm & ++ & +++ \\
\hline 16 & $29+1$ & 410 & 5 days & $\mathrm{M}$ & RDS & - & +++ \\
\hline 17 & $30+3$ & 1,430 & 3 days & $\mathrm{F}$ & RDS, fetofetal transfusion, asphyxia & & + \\
\hline \multicolumn{8}{|c|}{ Late RDS (over 7 days) } \\
\hline 18 & 25 & 3,170 & 4 days & $\mathrm{M}$ & IVH, BPD & - & ++ \\
\hline 19 & $30+4$ & 1,070 & 9 days & M & RDS, asphyxia & - & - \\
\hline \multicolumn{8}{|l|}{$\mathrm{BPD}$} \\
\hline 20 & 26 & 890 & 2 months & $\mathrm{M}$ & BPD, hydrocephalus & + & - \\
\hline 21 & $29+1$ & 765 & 4 months & $\mathrm{M}$ & $\mathrm{BPD}$, hemorrhage & - & - \\
\hline 22 & 25 & 1,070 & 5.5 months & M & BPD, Cor pulmonale & $-/+$ & + \\
\hline 23 & 41 & 800 & 9.5 months & $\mathrm{M}$ & $\mathrm{BPD}$, pneumonia & - & - \\
\hline 24 & 40 & 750 & 10 months & M & $\mathrm{BPD}$, pulmonary hypertension & $-/+$ & $-/+$ \\
\hline 25 & 28 & 805 & 7 months & $\mathrm{F}$ & $\mathrm{BPD}$, pneumonia & $-1+$ & $-1+$ \\
\hline
\end{tabular}

IVH = Intraventricular hemorrhage; HLHS = hypoplastic left heart syndrome.

intensity $(++)$ for $20-100 \%$ positive nuclei with at least moderate immunoreactivity, and high intensity $(+++)$ for $80-100 \%$ positive nuclei. For baboon samples, quantitation of staining was carried out using a semiquantitative scoring system $(0$ = negative, $1=$ mild, 2 = moderate, and 3 = intense staining). Preprepared tables were used listing the following structures and cell types: alveolar epithelium and bronchiolar/bronchial epithelium, arterial and capillary endothelium, and matrix cells (fibroblasts, smooth muscle cells).

\section{Cell Lines and TGF- $\beta$ Exposure in vitro}

Human A549 adenocarcinoma (American Type Culture Collection, Manassas, Va., USA) cells derived from alveolar type II cells and BEAS-2B cells (National Cancer Institute, Laboratory of Human Carcinogenesis, Dr. C. Harris, Bethesda, Md., USA), which are SV40-transformed human bronchial epithelial cells, were used for the in vitro experiments. The cell lines cells were grown in DMEM or bronchial epithelial cell growth medium supplemented with $10 \%$ FBS, $1 \%$ L-glutamine and $1 \%$ penicillinstreptomycin. The effect of TGF- $\beta$ on GATA- 6 and TTF- 1 transcription factors was evaluated in both cell lines by exposing the cells to 2 or $10 \mathrm{ng} / \mathrm{ml}$ of recombinant human TGF- $\beta_{1}$ (R\&D Systems), and the experiments were repeated three times. The cells were seeded on 6-well plates and allowed to attach and expand to subconfluency for $48 \mathrm{~h}$. The cells were serum starved for $24 \mathrm{~h}$, whereafter TGF- $\beta$ in DMEM supplemented with $1 \%$ FBS was added to the cells for $6 \mathrm{~h}$. After the exposure, the cells were harvested in RNA lysis buffer for RNA isolation.

\section{RNA Extraction and RT-PCR}

Total RNA was extracted from the A549 and BEAS-2B cells, and contaminating genomic DANN eliminated using RNeasy Mini Kit (Qiagen: 250, Cat. No. 74106). All experiments were repeated at least three times. First strand cDNA synthesis was per- 
Fig. 1. Expression of GATA-6 and TTF-1 transcription factors in human fetal (a and b) and term (c and d) lungs. Both GATA-6 and TTF-1 are expressed in the developing fetal airspaces, but not in term lungs. Bars $=200 \mu \mathrm{m}(\mathbf{a}-\mathbf{d})$. Arrowheads point at developing airspace epithelium (b) and alveolar epithelium $(\mathbf{d})$.

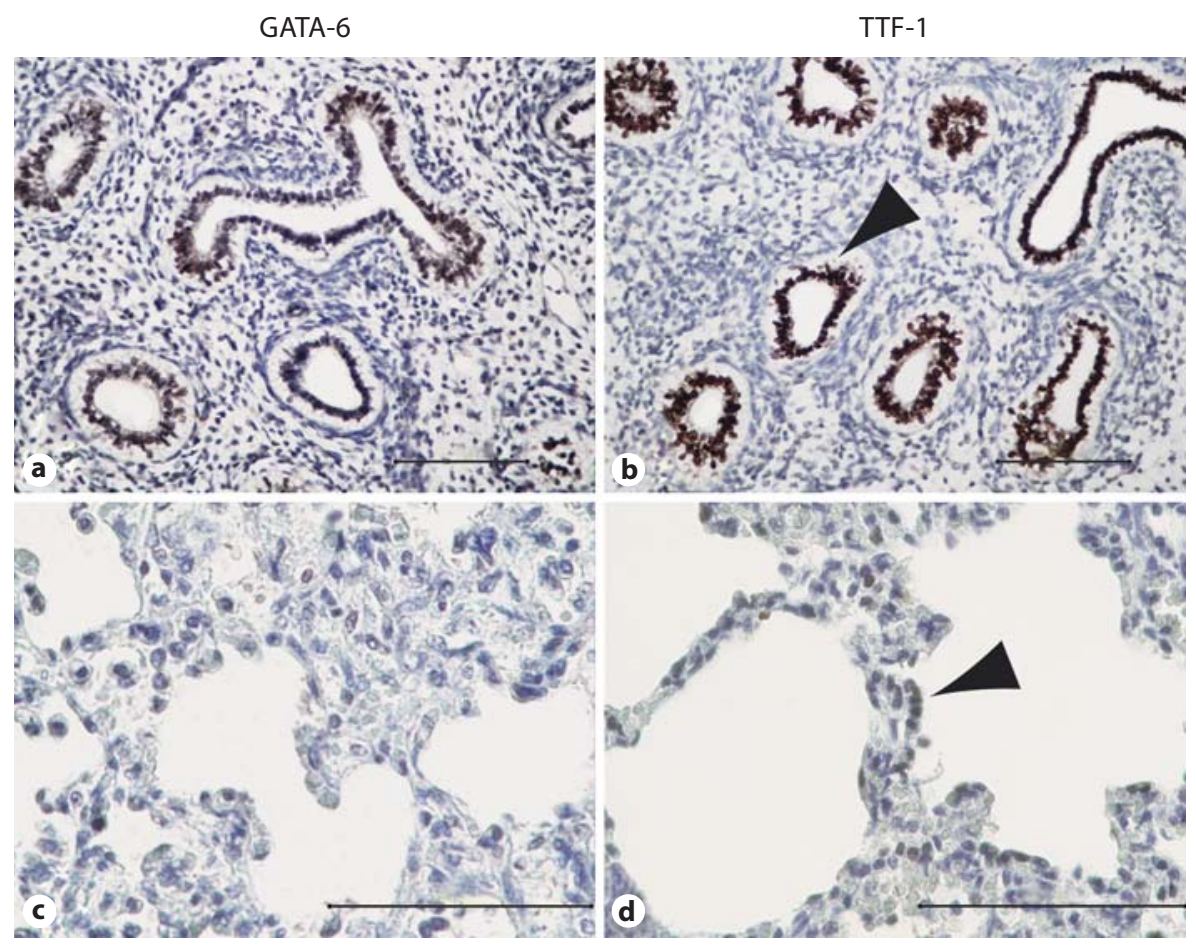

formed from $1 \mu \mathrm{g}$ of total RNA using $\mathrm{SYBR}^{\circledR}$ Green RT-PCR reagents and random hexamers (Applied Biosystems, Foster City, Calif., USA). The primers (Oligomer) were designed using the ABI Primer Express software (Applied Biosystems) applied to cDNA sequences derived from the UCSC Genome Bioinformatics Site web site (http://genome.ucsc.edu/) and were as follows: GATA-6 sense: 5'-ATG ACT CCA ACT TCC ACC TCT, GATA- 6 antisense 5'-CAG CCT CCA GAG ATG TGT AC G, TTF-1 sense 5'-CCT GGC GCT TCA TTT TGT AG, TTF-1 antisense 5'-ACC AGG ACA CCA TGA GGA AC, GAPDH sense 5'-TCA TTT CCT GGT ATG ACA ACG, GAPDH antisense 5'-TTA CTC CTT GGA GGC CAT GT. Analysis of GATA-4, GATA-6, TTF-1 and GAPDH expression was performed using the PTC-200 Peltier Thermal Cycler (MJ Research). Densitometric analysis on the bands was performed using Media Cybernetics Image J software for Macintosh.

\section{Results}

GATA-6 Expression Is High in Human Fetal Lung Epithelium and Diminishes towards Term

GATA-6 expression could be detected in early human fetal lung, and it localized to the developing airway epithelium (fig. 1). The early fetal pulmonary tissue (pseudoglandular phase of development, $<18$ weeks) lacks a mature alveolar epithelium and the alveolar wall is lined by a non-differentiated epithelial cell layer that can be identified by a typical morphology. Intensive GATA-6 immu- noreactivity was detectable in these early terminal airspaces (fig. 1a). In addition to the saccular epithelial cells, some positivity was observed within the developing bronchial epithelial cells (not shown). The parenchymal tissue in the developing lung in turn, consists of a relatively thick, loose layer of fibroblasts and connective tissue. No GATA-6 immunoreactivity was observed in the parenchymal fibroblasts. With advancing gestational age, expression confined to the epithelial cells, presumably type II cells. The staining intensity at this time was, however, clearly weaker than in early fetal period (fig. 1c; table 1).

\section{TTF-1 Expression Follows Epithelial GATA-6}

Expression in the Developing Human Lung

Next, we wanted to analyze the expression of a pulmonary GATA-6 cofactor and putative target gene TTF-1 during lung development. TTF-1 expression is generally confined to the saccular/alveolar epithelial cells in the developing lung. TTF-1 was expressed in the human fetal lung very similarly to GATA-6 (table 1 ; fig. 1b, d), confining to the developing alveolar epithelial cells. Similarly, the intensity of TTF-1 was higher in the earlier phases of development. The lung parenchymal tissue was always TTF-1 negative. The expression of TTF-1 in bronchial epithelial cells varied between individual samples, so that weak to intensive staining was observed (not shown). 
Fig. 2. Immunohistochemical staining with specific antibodies for GATA- 6 and TTF-1 transcription factors at various stages of human RDS (GATA-6: a, c, e; TTF-1: b, d, f) and in BPD (GATA-6: g; TTF-1: h). Note that the expression of GATA- 6 and TTF-1 is highest in RDS prolonged for 3-7 days (c and d). Bars $=200$ $\mu \mathrm{m}(\mathbf{a}-\mathbf{h})$.
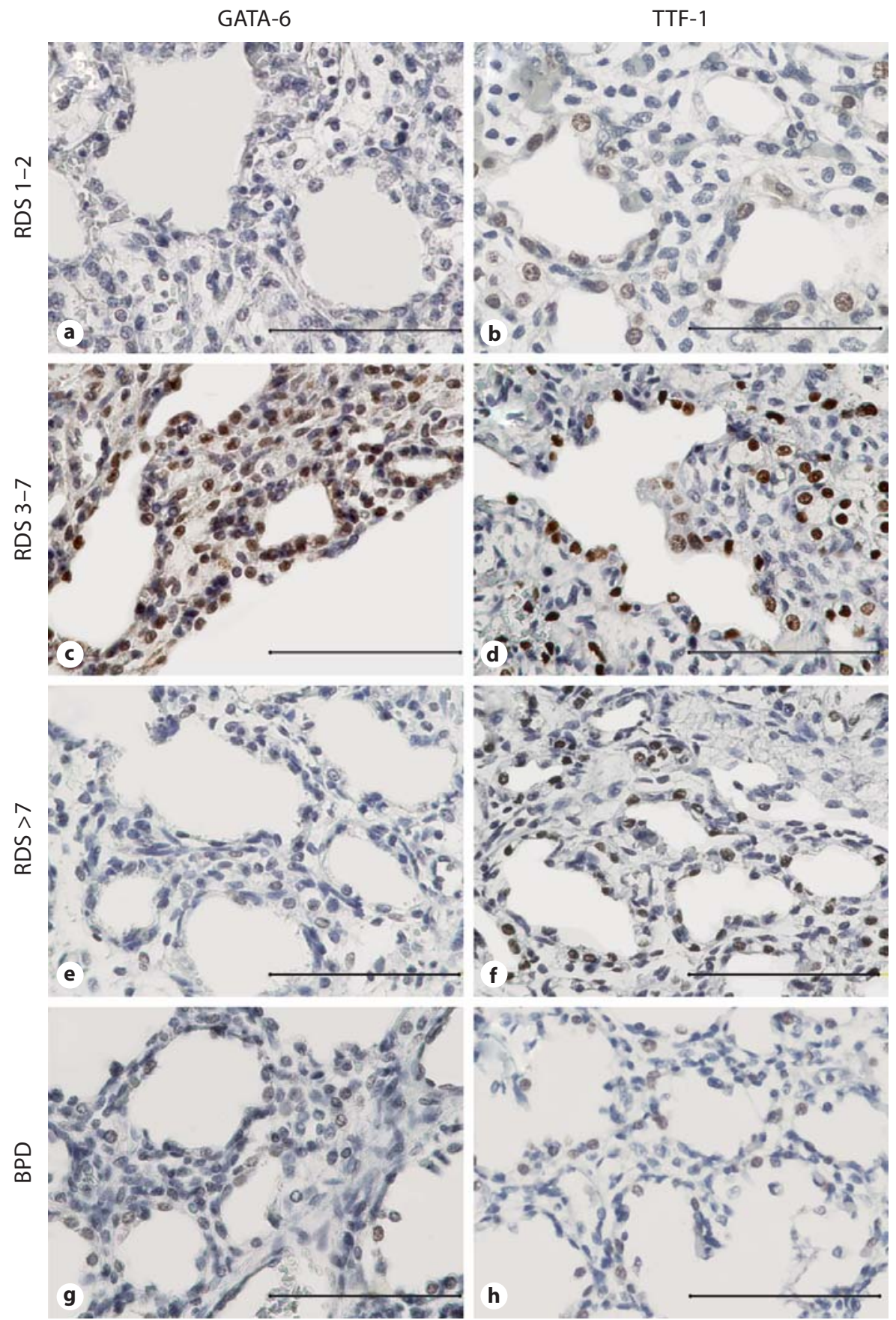

Pulmonary Epithelial GATA-6 Expression Is First

Enhanced in RDS, but Then Decreases with Prolonged

Disease and the Development of BPD in Premature

Lung

To assess the relationship of GATA- 6 expression with the duration and/or severity of neonatal lung disease, three groups of neonates with RDS of varying length of the disease and 2 neonates with BPD were analyzed. GATA-6 expression was studied in three distinct phases of RDS: 1-2 days, 3-7 days or over 7 days after birth. In addition, six samples from patients with BPD were included.

The staining for GATA- 6 was strongest in the airway epithelium of the group with intermediate-length (3-7 
Table 2. Immunohistochemical assessment of GATA- 6 in fetal and preterm baboon lung

\begin{tabular}{|c|c|c|c|c|c|c|}
\hline Group & $\begin{array}{l}\text { Alveolar } \\
\text { epithelium }\end{array}$ & $\begin{array}{l}\text { Bronchial- } \\
\text { bronchiolar } \\
\text { epithelium }\end{array}$ & Fibroblast & $\begin{array}{l}\text { Arterial } \\
\text { smooth } \\
\text { muscle }\end{array}$ & $\begin{array}{l}\text { Arterial } \\
\text { endothelium }\end{array}$ & $\begin{array}{l}\text { Capillary } \\
\text { endothelium }\end{array}$ \\
\hline \multicolumn{7}{|l|}{ GC } \\
\hline 125 days & $1.5(1-3)$ & $1.3(0-3)$ & $1.3(1-2)$ & $1.5(0-2)$ & $1.8(1-3)$ & $0(0)$ \\
\hline 140 days & $1.6(1-2)$ & $1.2(0-2)$ & $1.4(1-2)$ & $1.4(1-2)$ & $2(1-3)$ & $0.6(0-2)$ \\
\hline 160 days & $1.5(1-2)$ & $1.3(1-3)$ & $0.8(0-1)$ & $0.5(0-2)$ & $1.5(1-2)$ & $0.3(0-1)$ \\
\hline 175 days & $1.3(1-2)$ & $0.8(0-2)$ & $1(0-2)$ & $0.3(0-1)$ & $0.8(0-1)$ & $0.3(0-1)$ \\
\hline Term & $1.5(1-2)$ & $0.9(0-2)$ & $0.8(0-2)$ & $0.5(0-1)$ & $0.8(0-1)$ & $0(0)$ \\
\hline $125+2$ days $\mathrm{PRN} \mathrm{O}_{2}$ & $2(1-3)$ & $1.8(1-2)$ & $1.5(1-2)$ & $0.5(0-1)$ & $1.3(1-2)$ & $0(0)$ \\
\hline $125+6$ days $\mathrm{PRN} \mathrm{O}_{2}$ & $2(2)$ & $2(1-3)$ & $1.8(1-2)$ & $0.8(0-2)$ & $1.8(1-2)$ & $1.8(0-3)$ \\
\hline $125+14$ days $\mathrm{PRN} \mathrm{O}_{2}$ & $1.3(1-3)$ & $0.6(0-2)$ & $0.7(0-1)$ & $0.7(0-2)$ & $0.8(0-3)$ & $0.3(0-1)$ \\
\hline $125+21$ days $\mathrm{PRN} \mathrm{O}_{2}$ & $1.4(1-2)$ & $1.2(0-2)$ & $1.4(1-2)$ & $0.8(0-1)$ & $0.8(0-1)$ & $0.2(0-1)$ \\
\hline
\end{tabular}

A semiquantitative scoring system was used $(0=$ negative, $1=$ weak, $2=$ moderate, $3=$ intense staining). Results are shown as mean (range).

days) RDS (fig. 2c), and decreased thereafter (fig. 2e-g; table 1). In all groups, GATA-6 expression was stronger in the alveolar epithelium than in the bronchial epithelium. In 2/4 1- to 2-day RDS samples (table 1; patients 8 and 9), the alveolar epithelium showed weak positive GATA- 6 immunoreactivity, and the expression intensified in the 3-7 days group (table 1; patients 12-15). Of interest, some parenchymal cells in the 3- to 7-day RDS group were GATA- 6 positive in specimens, in which epithelial positivity was also observed (fig. $2 \mathrm{c}$ ). In the patient group with prolonged RDS ( $>7$ days), GATA-6 levels were lower than in the two other RDS groups, and the positive cells were observed only in the peribronchial and parenchymal fibroblasts (fig. 2e).

If RDS leads to BPD, the morphology of the lung parenchyma is altered so that the reactive alveolar epithelium in RDS is replaced by - or difficult to distinguish from - an increased population of parenchymal fibroblasts. In the neonatal lungs with typical BPD, the epithelial GATA-6 staining was almost negligible with only some positivity in the peribronchial fibroblasts (fig. $2 \mathrm{~g}$ ).

All in all, GATA- 6 expression is enhanced during the first week of RDS and decreases along with the duration of the disease. GATA- 6 localizes to the reactive epithelium and the parenchymal fibroblasts beneath it.

Expression of TTF-1 Resembles That of GATA-6 in the Human RDS Lung

Next, we wanted to analyze the expression of TTF-1 duringlung development and disease. Similarly to GATA-
6, epithelial TTF-1 expression was high in early fetal lung and decreased towards term (fig. $1 \mathrm{~b}, \mathrm{~d}$ ). The pulmonary TTF-1 expression in neonatal lung disease (fig. 2; table 1) coincided partially with that of GATA-6, with the exception that alveolar epithelial cells showed positivity for TTF-1 already in 1- to 2-day RDS (fig. 2b). TTF-1 expression was strongest in intermediate/long disease (fig. $2 \mathrm{~d}$, f) and negligible in BPD, only very weak immunoreactivity being observed in the alveolar epithelium (fig. $2 \mathrm{~h}$ ). In contrast to GATA-6 staining, TTF-1 was not detected in the parenchyma, but was solely confined to type II epithelial cells; this finding is in accordance with earlier reports on the specificity of TTF-1 as a marker of type II cells $[24,25]$.

\section{GATA-6 Expression in Fetal and Preterm Baboon Lung}

Studies using human tissues are challenging due to difficulties in obtaining samples from large numbers of individuals and especially from healthy, age-matched controls. We therefore confirmed and extended our results of GATA-6 in human material in an established baboon model of prematurity. During the last trimester of baboon gestation, there was a trend toward decreased expression of GATA- 6 protein in bronchiolar epithelium. In addition, the cells that had an appearance of interstitial fibroblasts, and arterial smooth muscle and endothelial cells had less GATA-6 immunoreactivity (table 2). There was a moderate, but unchanged, GATA- 6 positivity in alveolar epithelium during fetal baboon ontogenesis (table 2). 
Fig. 3. Immunohistochemical staining with an antibody for GATA-6 transcription factor in baboon RDS and BPD. In RDS, enhanced GATA-6 immunoreactivity was observed in the terminal airspaces (arrow), bronchiolar epithelium (br) and arterial wall (ar) of $125+6$ days PRN O baboons (b) compared with age-matched GCs (a; 125 days' gestation). a Alveolar epithelium is marked by an arrow. In evolving BPD, GATA- 6 expression decreased in the bronchiolar epithelium (br) of $125+14$ days PRN $\mathrm{O}_{2}$ animals (d) when compared with age-matched fetal controls (c; 140 days' gestation GCs). Arrows point at alveolar epithelium. $\mathrm{ca}=$ Capillaries. Bars $=$ $400 \mu \mathrm{m}$ (a-d).

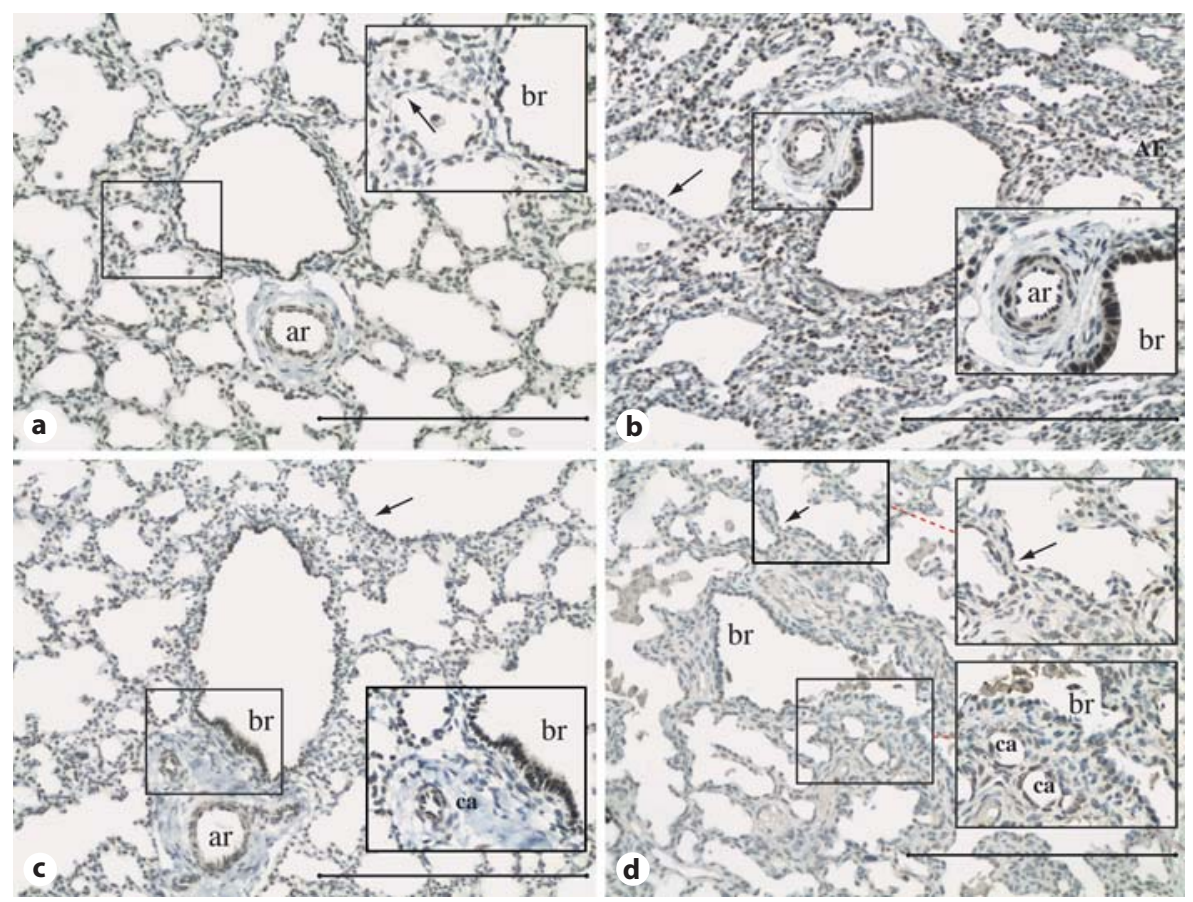

GATA- 6 expression was somewhat increased in baboon RDS $\left(125+2\right.$ or 6 days $\mathrm{PRN} \mathrm{O}_{2}$; table 2; fig. $\left.3 \mathrm{~b}\right)$ compared with age-matched GCs (fig. 3a). Specifically, there was a stronger GATA- 6 expression in bronchiolar epithelium of $125+2$ and/or 6 days PRN $\mathrm{O}_{2}$ baboons compared with age-matched GCs (125 days' gestation; table 2). Moreover, the high GATA-6 expression in baboon RDS appeared to decrease in evolving BPD (125+ 14 days PRN $\mathrm{O}_{2}$ ), especially in saccular/alveolar and bronchiolar epithelium (table 2). When compared with the age-matched fetal controls (140 days' gestation GCs; fig. 3c), GATA-6 immunoreactivity was diminished in evolving $\left(125+14\right.$ days $\left.\mathrm{PRN} \mathrm{O}_{2}\right)$, but not in the more established $\left(125+21\right.$ days $\left.\mathrm{PRN} \mathrm{O}_{2}\right)$ baboon BPD (table 2; fig. $3 \mathrm{~d}$ ). The nonimmune serum and/or secondary antibody without primary antibody controls was negative for each section (not shown).

\section{TGF- $\beta$ Upregulates GATA-6 and TTF-1 mRNA}

Expression in Pulmonary Epithelial Cell Lines

Several lines of evidence implicate TGF- $\beta$ as a central regulator of tissue repair and profibrotic signaling, especially in the lung. Possible regulation of GATA- 6 by TGF- $\beta$ was investigated in two established pulmonary epithelial cell lines, A549 and BEAS-2B. Neither cell line expressed detectable levels of GATA- 6 before the treat- ment with TGF- $\beta$ (fig. 4 for A549; data not shown for BEAS-2B). Recombinant TGF- $\beta_{1}$ in concentrations of 2 and $10 \mathrm{ng} / \mathrm{ml}$ upregulated GATA- 6 mRNA expression in the two cell lines (fig. 4 for A549; data not shown for BEAS-2B), and a more pronounced effect was detectable at the $2 \mathrm{ng} / \mathrm{ml}$ concentration, which is the biologically effective dose used widely in TGF- $\beta$ research. To test whether GATA- 6 would act specifically as a mediator of the TGF- $\beta$ effects, RT-PCR for GATA- 4 , a closely related gene to GATA- 6 also expressed in the lung, was performed as a control. In contrast to GATA- 6 mRNA expression, there was a small decrease in GATA-4 levels ( $40 \%$ in the $2 \mathrm{ng} / \mathrm{ml}$ group and and 70\% in the $10 \mathrm{ng} / \mathrm{ml}$ group) in treated versus untreated cells in A549 cells (fig. 4), and in the BEAS-2B cells no detectable levels of GATA-4 were found in any group, stimulated or nonstimulated (not shown). The effect of TGF- $\beta$ on the TTF1 mRNA by RT-PCR was investigated next, and, similarly to GATA- 6 , TTF- 1 was induced slightly by TGF- $\beta$ (fig. 4; data not shown for BEAS-2B cells). A basal expression of TTF-1 level was also detectable in the non-stimulated cells. GAPDH levels remained unchanged in the stimulated versus nonstimulated cells (fig. 4 for A549; data not shown for BEAS-2B). 


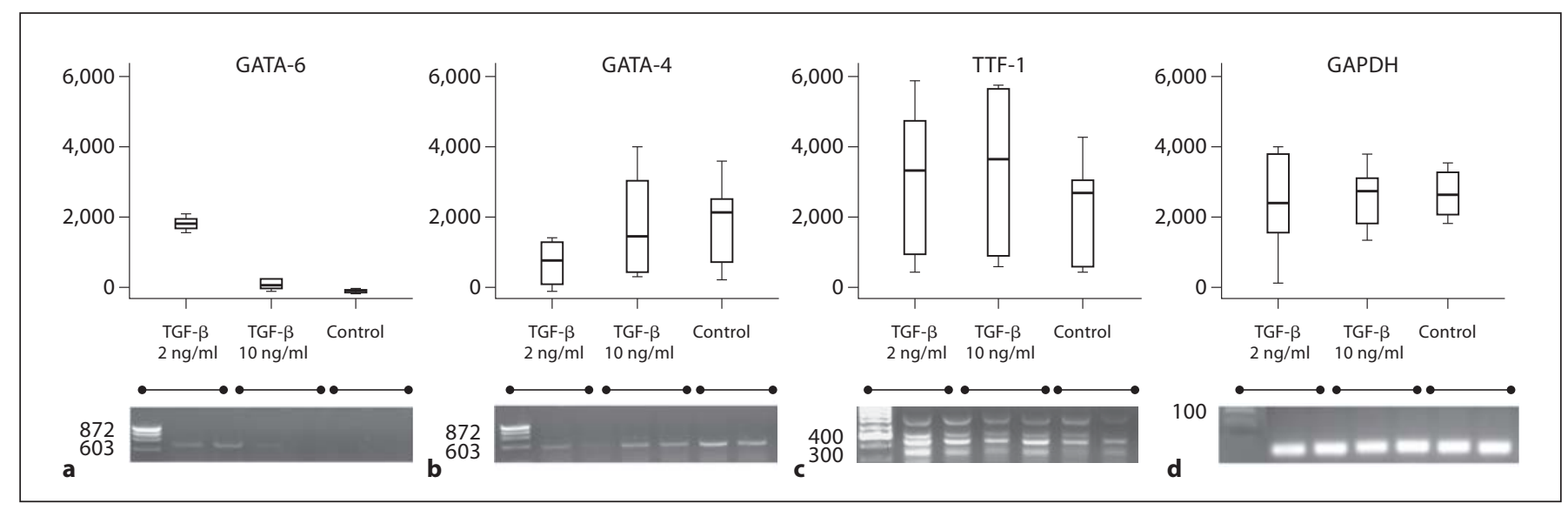

Fig. 4. Expression of GATA-6 (a), GATA-4 (b), TTF-1 (c) and GAPDH (d) mRNA as detected by RT-PCR in A549 cell line presented as boxplots (median, 25th and 75th percentile and the highest and lowest value presented from at least three experiments quantitated densitometrically, and a representative gel is shown below each boxplot).

\section{Discussion}

Acute RDS and BPD remain central problems in the care of preterm infants. Several advances have been encountered in the understanding of these conditions during the last decades, albeit there are still open questions in the underlying molecular mechanisms. We herein utilized prenatal and neonatal human and baboon lung samples, and performed cell culture studies to elucidate the role of TGF- $\beta$ and transcription factor GATA- 6 as well as their cooperation in lung epithelial cells in these central neonatal diseases.

The pathogenesis of BPD is multifactorial, but the developmental arrest of alveolarization and inflammatory processes are key aberrations leading to this disease [2, $26,27]$. In the baboon model, equivalent to about 26 weeks of gestation in humans, the preterm animals develop alveolar hypoplasia and variable saccular wall fibrosis analogous to the pathology in lungs of human preterm infants [21]. We now show, both in preterm infants and in the baboon model that the development of chronic lung disease associates with increased expression of transcription factors GATA- 6 and TTF-1 in the respiratory epithelium. Using a transgenic mouse model, others have previously demonstrated that increased GATA- 6 expression in respiratory epithelial cells results in impaired pulmonary alveolarization and limited septation, thereby causing a histologic pattern resembling that of primate BPD [13]. In addition, the expression of GATA- 6 was induced by TGF- $\beta$ in human epithelial cell cultures.
Earlier work has revealed that TGF- $\beta$ regulates and cooperates with GATA proteins in other tissues $[28,29]$. It is noteworthy that in the pulmonary epithelial cell cultures, the effect of TGF- $\beta$ was noted to regulate GATA- 6 mRNA expression, whereas GATA-4, another GATA factor implicated in the lungs, was not stimulated. This implies that, of the GATA factors, GATA- 6 participates in the regulation of abnormal processes in the neonatal lung. This hypothesis is further supported by recent findings showing that GATA- 6 is crucial at all stages of pulmonary epithelial development and regeneration: it mediates epithelial stem cell development [30], TGF- $\beta$-induced epithelial mesenchymal transition and the differentiation of fibroblasts to myofibroblasts [31].

The transcriptional control of lung morphogenesis is complex. In the mouse, GATA- 6 is required for the survival of progenitor cells for the bronchiolar epithelium, and it is essential for early differentiation and maturation of the lung $[12,30,32]$. We found that in the human lung, GATA-6 immunoreactivity in the airway epithelium was high during the second trimester, but diminished significantly towards term. This developmental pattern resembles the one in mice [13] and suggests a physiologic role for GATA-6 in human pulmonary development. Of note, the expression of TTF-1, a transcription factor related to GATA-6 in the regulation of lung-specific gene expression [14], coincided with that of GATA-6 during development indicating their co-operation also in the human lung. GATA-6, together with TTF-1, is a known regulator of surfactant proteins A and C $[14,15]$. It is possible that 
in the early phase of neonatal lung disease, the induction of GATA- 6 and TTF-1 expression ensures surfactant synthesis in the type II pulmonary epithelial cells. In the RDS airway epithelium, increased GATA- 6 and TTF-1 expression was first observed, but this subsequently decreased along with the prolongation of lung disease. The induction of these genes may be related to a protective induction in surfactant production by the alveolar epithelium, and later reflect epithelial injury often observed in late RDS.

Intrauterine as well as postnatal inflammatory processes are important in the pathogenesis of BPD [2]. However, the relationship between inflammation and developmental arrest is poorly understood $[26,33]$. The TGF family of growth factors, e.g. TGF- $\beta$ and bone morphogenetic proteins play a crucial role in the regulation of lung development and homeostasis [34]. Aberrant expression and activation of TGF- $\beta$ are associated with abnormal lung development and pulmonary fibrosis both in the newborn and adult lung. Enhanced expression and activation of latent TGF- $\beta$ contributes to pulmonary fibrosis progression $[34,35]$, and high concentrations of TGF- $\beta$ have been observed in the pulmonary fluid of preterm infants [36]. Enhanced TGF- $\beta$ activation with consequent GATA- 6 upregulation in the preterm lung may, in part, explain the development of BPD after inflammatory and hyperoxic injury to the lung. This hypothesis is further supported by the finding that TGF- $\beta$ enhances GATA- 6 expression in two different pulmonary epithelial cell lines. Transformed, adult cell lines were used due to the lack of suitable human embryonic or neonatal cell lines.

This is the first study to describe the temporal expression of GATA-6 in the developing normal and diseased lung. There are, however, obvious limitations to the conclusions that can be drawn from these data. It is practi- cally impossible to find suitable control samples when assessing human RDS and BPD tissue samples. The sample size is rather small, as these are autopsied cases. It is therefore possible that differences in the fixation in premature versus term lungs compromise the finding on downregulated expression of GATA- 6 and TTF-1 expression in the term lung, especially when this finding was not observed in the uniformly processed baboon lung.

All in all, earlier and current data reveal a temporal expression pattern for GATA-6 during fetal lung development in the mouse, baboon and human. In agreement with the earlier work in mice [13], enhanced postnatal expression of GATA- 6 and TTF-1 in pulmonary epithelium associates with the development of chronic lung disease in human preterm babies and baboons. Furthermore, TGF- $\beta$ enhances the expression of GATA- 6 and TTF-1 in human epithelial cell cultures. Signaling cascades involving TGF- $\beta$, GATA- 6 and TTF- 1 can be speculated to play an important role in the pathogenesis of $\mathrm{BPD}$ in preterm infants.

\section{Acknowledgements}

This study was supported by grants from Sigrid Jusélius Foundation (to S.A., M.H., M.M.) and the Finnish Foundation for Pediatric Research (to R.V., S.A., M.H., M.M.), the Academy of Finland (to M.H. and M.M.), the Finnish Medical Foundation (M.M.), University Central Hospital research Grants (to V.L.K., S.A., M.H., M.M.), Finska Läkaresällskapet (to S.A., M.M.) and the Finnish Antituberculosis Association Foundation (V.L.K., M.M.). Nonhuman primate studies were supported by NIH grant UO1 HL56263 (to T.M.A., C.W.W.).

We thank Ms. Taru Jokinen for expert technical assistance, and Prof. David B. Wilson for critical reading of the manuscript. We are grateful to docent Caj Haglund for providing us help with BPD sample preparation in his laboratory.

\section{References}

-1 Verma RP: Respiratory distress syndrome of the newborn infant. Obstet Gynecol Surv 1995;50:542-555.

2 Speer CP: Inflammation and bronchopulmonary dysplasia: a continuing story. Semin Fetal Neonatal Med 2006;11:354-362.

3 Jobe AJ: The new BPD: an arrest of lung development. Pediatr Res 1999;46:641-643.

4 Abman SH: Bronchopulmonary dysplasia: 'a vascular hypothesis'. Am J Respir Crit Care Med 2001;164:1755-1756.

-5 Alejandre-Alcazar MA, Kwapiszewska G, Reiss I, Amarie OV, Marsh LM, Sevilla-Perez J, Wygrecka M, Eul B, Kobrich S, Hesse M,
Schermuly RT, Seeger W, Eickelberg O, Morty RE: Hyperoxia modulates TGF-beta/ BMP signaling in a mouse model of bronchopulmonary dysplasia. Am J Physiol Lung Cell Mol Physiol 2007;292:L537-L549.

6 Orkin SH: GATA-binding transcription factors in hematopoietic cells. Blood 1992;80: 575-581

7 Arceci RJ, King AA, Simon MC, Orkin SH, Wilson DB: Mouse GATA-4: a retinoic acidinducible GATA-binding transcription factor expressed in endodermally derived tissues and heart. Mol Cell Biol 1993;13: 2235-2246.
8 Morrisey EE, Ip HS, Tang Z, Lu MM, Parmacek M: GATA-5: a transcriptional activator expressed in a novel temporally and spatially-restricted pattern during embryonic development. Dev Biol 1997;183:21-36.

\9 Morrisey EE, Ip HS, Lu MM, Parmacek MS: GATA-6: a zinc finger transcription factor that is expressed in multiple cell lineages derived from lateral mesoderm. Dev Biol 1996; 177:309-322.

10 Ackerman KG, Wang J, Luo L, Fujiwara Y, Orkin SH, Beier DR: Gata4 is necessary for normal pulmonary lobar development. Am J Respir Cell Mol Biol 2007;36:391-397. 
-11 Jay PY, Bielinska M, Erlich JM, Mannisto S, $\mathrm{Pu}$ WT, Heikinheimo M, Wilson DB: Impaired mesenchymal cell function in Gata4 mutant mice leads to diaphragmatic hernias and primary lung defects. Dev Biol 2007;301: 602-614.

12 Liu C, Morrisey EE, Whitsett JA: GATA-6 is required for maturation of the lung in late gestation. Am J Physiol Lung Cell Mol Physiol 2002;283:L468-L475.

-13 Liu C, Ikegami M, Stahlman MT, Dey CR, Whitsett JA: Inhibition of alveolarization and altered pulmonary mechanics in mice expressing GATA-6. Am J Physiol Lung Cell Mol Physiol 2003;285:L1246-L1254.

- 14 Liu C, Glasser SW, Wan H, Whitsett JA: GATA-6 and thyroid transcription factor-1 directly interact and regulate surfactant protein-C gene expression. J Biol Chem 2002; 277:4519-4525.

-15 Bruno MD, Korfhagen TR, Liu C, Morrisey EE, Whitsett JA: GATA-6 activates transcription of surfactant protein A. J Biol Chem 2000;275:1043-1049.

16 Shaw-White JR, Bruno MD, Whitsett J: GATA- 6 activates transcription of thyroid transcription factor-1. J Biol Chem 1999;274: 2658-2664.

- 17 Ballard PL, Ballard RA, Ning Y, Cnann A, Boardman C, Pinto-Martin J, Polk D, Phibbs RH, Davis DJ, Mannino FL, Hart M: Plasma thyroid hormones in premature infants: effect of gestational age and antenatal thyrotropin-releasing hormone treatment. TRH Collaborative Trial Participants. Pediatr Res 1998;44:642-649.

18 Vicencio AG, Lee CG, Cho SJ, Eickelberg O, Chuu Y, Haddad GG, Elias J: Conditional overexpression of bioactive transforming growth factor-betal in neonatal mouse lung: a new model for bronchopulmonary dysplasia? Am J Respir Cell Mol Biol 2004;31:650656.
19 Nakanishi H, Sugiura T, Streisand JB, Lonning SM, Roberts JD Jr: TGF-beta-neutralizing antibodies improve pulmonary alveologenesis and vasculogenesis in the injured newborn lung. Am J Physiol Lung Cell Mol Physiol 2007;293:L151-L161.

20 Jobe AH, Bancalari E: Bronchopulmonary dysplasia. Am J Respir Crit Care Med 2001; 163:1723-1729.

-21 Coalson JJ, Winter VT, Siler-Khodr T, Yoder BA: Neonatal chronic lung disease in extremely immature baboons. Am J Respir Crit Care Med 1999;160:1333-1346.

-22 Asikainen TM, Waleh NS, Schneider BK, Clyman RI, White C: Enhancement of angiogenic effectors through hypoxia-inducible factor in preterm primate lung in vivo. Am J Physiol Lung Cell Mol Physiol 2006; 291:L588-L595.

-23 Anttonen M, Unkila-Kallio L, Leminen A, Butzow R, Heikinheimo M: High GATA-4 expression associates with aggressive behavior, whereas low anti-Mullerian hormone expression associates with growth potential of ovarian granulosa cell tumors. J Clin Endocrinol Metab 2005;90:6529-6535.

24 Ikeda K, Clark JC, Shaw-White JR, Stahlman MT, Boutell CJ, Whitsett JA: Gene structure and expression of human thyroid transcription factor-1 in respiratory epithelial cells. J Biol Chem 1995;270:8108-8114.

25 Stahlman MT, Gray ME, Whitsett JA: Expression of thyroid transcription factor-1 (TTF-1) in fetal and neonatal human lung. J Histochem Cytochem 1996;44:673-678.

$\checkmark 26$ Le Cras TD, Hardie WD, Deutsch GH, Albertine KH, Ikegami M, Whitsett JA, Korfhagen TR: Transient induction of TGF-alpha disrupts lung morphogenesis, causing pulmonary disease in adulthood. Am J Physiol Lung Cell Mol Physiol 2004;287:L718-L729.

$\checkmark 27$ Thebaud B, Abman SH: Bronchopulmonary dysplasia: where have all the vessels gone? Roles of angiogenic growth factors in chronic lung disease. Am J Respir Crit Care Med 2007;175:978-985.

-28 Anttonen M, Parviainen H, Kyronlahti A, Bielinska M, Wilson DB, Ritvos O, Heikinheimo M: GATA-4 is a granulosa cell factor employed in inhibin-alpha activation by the TGF-beta pathway. J Mol Endocrinol 2006; 36:557-568.
29 Viger RS, Guittot SM, Anttonen M, Wilson DB, Heikinheimo M: Role of the GATA family of transcription factors in endocrine development, function, and disease. Mol Endocrinol 2008;22:781-798.

-30 Zhang Y, Goss AM, Cohen ED, Kadzik R, Lepore JJ, Muthukumaraswamy K, Yang J, DeMayo FJ, Whitsett JA, Parmacek MS, Morrisey EE: A Gata6-Wnt pathway required for epithelial stem cell development and airway regeneration. Nat Genet 2008;40: 862-870.

>31 Leppäranta O, Pulkkinen V, Koli K, Vähätalo R, Salmenkivi K, Kinnula VL, Heikinheimo M, Myllärniemi M: Transcription factor GATA-6 is expressed in quiescent myofibroblasts in idiopathic pulmonary fibrosis. Am J Respir Cell Mol Biol 2010;42: 626-632.

-32 Morrisey EE, Tang Z, Sigrist K, Lu MM, Jiang F, Ip HS, Parmacek MS: GATA6 regulates HNF4 and is required for differentiation of visceral endoderm in the mouse embryo. Genes Dev 1998.12:3579-3590.

$\checkmark 33$ Massaro D, Massaro G: Critical period for alveologenesis and early determinants of adult pulmonary disease. Am J Physiol Lung Cell Mol Physiol 2004;287:L715-L717.

34 Koli K, Myllarniemi M, Keski-Oja J, Kinnula V: Transforming growth factor-beta activation in the lung: focus on fibrosis and reactive oxygen species. Antioxid Redox Signal 2008;10:333-342.

>35 Xu YD, Hua J, Mui A, O’Connor R, Grotendorst G, Khalil N: Release of biologically active TGF-beta1 by alveolar epithelial cells results in pulmonary fibrosis. Am J Physiol Lung Cell Mol Physiol 2003;285:L527-L539.

>36 Kotecha S, Wangoo A, Silverman M, Shaw $\mathrm{RJ}$ : Increase in the concentration of transforming growth factor beta-1 in bronchoalveolar lavage fluid before development of chronic lung disease of prematurity. J Pediatr 1996;128:464-469. 